\title{
Recorregut de recerca geològica i mineralògica per la comarca del Pallars jussà: des de la Torre de Cabdella cap a Espui, Cabdella, Sallente i cap I'Estany Gento
}

Josep Maria Mata-Perelló

Joaquim Sanz Balagué

\section{XARAGALL \\ REVISTA DE CIÈNCIES DE LA CATALUNYA CENTRAL} n. 8

AGOST 2014 


\title{
RECORREGUT DE RECERCA GEOLÒGICA I MINERALÒGICA PER LA COMARCA DEL PALLARS JUSSÀ: DES DE LA TORRE DE CABDELLA CAP A ESPUI, CABDELLA, SALLENTE I CAP L'ESTANY GENTO
}

\author{
Josep Maria Mata-Perelló \\ Museu de geologia Valentí Masachs, Escola Politècnica Superior d'Enginyeria de Manresa \\ (EPSEM), Universitat Politècnica de Catalunya · BarcelonaTech (UPC), 08272 Manresa, Spain
}

\section{Joaquim Sanz Balagué}

Departament d'Enginyeria Minera i Recursos Naturals (EMRN), Escola Politècnica Superior d'Enginyeria de Manresa (EPSEM), Universitat Politècnica de Catalunya - BarcelonaTech (UPC), 08272 Manresa, Spain

Paraules clau: materials paleozoics; Unitat de les Nogueres; Zona axial pirinenca; Patrimoni miner

\section{Resum}

Itinerari realitzat el 7 de setembre de 2013. En aquesta ocasió, la totalitat del recorregut de l'itinerari es desenvoluparà per una sola unitat geològica: concretament pel Sistema Pirinenc, i més exactament per la zona de contacte entre la Unitat de les Nogueres i la Zona Axial Pirinenca, situada al nord de l'anterior. D'aquesta manera, el recorregut s'iniciarà a la població de la Torre de Cabdella (situada a la Unitat de les Nogueres), per a finalitzar a l'Estany Gento (situat ja dintre de la Zona Axial Pirinenca).

Així, a partir de la Torre de Cabdella, l'itinerari transitarà per la primera unitat esmentada, anant cap a les poblacions d’Espui i de Cabdella. Més amunt, per les immediacions de Sallente, s'arribarà al contacte amb la Zona Axial Pirinenca, que ja no s'abandonarà en tota la resta del recorregut.

Així, inicialment, s'aniran trobant afloraments dels materials paleozoics del Silurià i del Devonià. Més endavant, en arribar a la Zona Axial, es trobaran granits i granodiorites carboníferes., així com afloraments paleozoics de I'Ordovicià, Silurià i Devonià, fonamentalment.

Per d'altra banda, aquest itinerari es desenvoluparà dintre de la comarca del Pallars Jussà (per la qual es transitarà entre la població de la Torre de Cabdella i la fi del recorregut, per les immediacions de l'Estany Gento). Així, tot el recorregut de l'itinerari s'efectuarà per la part més alta de la Vall Fosca, una subcomarca del Pallars Jussà. Aquesta subcomarca es troba situada íntegrament dintre de la conca fluvial del Noguera de Flamisell, afluent del Noguera Pallaresa a la Pobla de Segur. 


\section{Objectius fonamentals}

Es centraran en els aspectes geològics, geomorfològics i mineralògics que apuntarem a continuació:

1. Observació dels materials que constitueixen la Unitat de les Nogueres, que anirem trobant entre la Torre de Cabdella i les immediacions de Cabdella (tot anant cap a Sallente). Aquests materials pertanyen, en aquest tram, exclusivament al paleozoic (repartint-se entre el Carbonífer, el Devonià i el Silurià). Així, trobarem afloraments del Carbonífer (amb trams d'esquistos negres, fonamentalment), del Devonià (amb trams de calcàries ) i del Silurià (amb pissarres negres, molt grafitoses i piritoses).

2. Observació dels materials que constitueixen la Zona Axial Pirinenca, que anirem trobant entre les immediacions de Cabdella i la fi del recorregut. Aquests materials pertanyen, exclusivament al paleozoic (entre el Carbonífer, el Devonià, el Silurià i l'Ordovicià). Així, trobarem afloraments de I'Ordovicià (amb trams d'esquistos, fonamentalment), del Silurià (amb pissarres negres, molt grafitoses i piritoses), del Devonià (amb trams de calcàries ) i del Carbonífer (amb granits i granodiorites).

3. Observació de les relacions existents entre les dues subunitats pirinenques acabades d'esmentar, entre la Unitat del Mantell de les Nogueres i la Zona Axial Pirinenca.

4. Observació de les diferents mineralitzacions que anirem trobant al llarg del recorregut, si es dona el cas. Tot i així, cal dir que no en trobarem gaires.

5. Observació al llarg del recorregut de l'itinerari de les antigues explotacions situades al llarg del recorregut. Aquest és el cas de l'extracció d'àrids, per a la construcció de la Presa de l’Embassament de Sallente.

6. Observació de l'impacte produït sobre el Medi Natural, tant de la mineria com a conseqüència de les obres efectuades per la zona. I també, si es dona el cas: observació de les restauracions dutes a terme, per tal de mitigar aquest impacte.

7. Observació dels indrets relacionats amb el patrimoni geològic, que es vagi trobant al llarg del recorregut. Dintre d'aquest apartat, cal fer esment del Patrimoni Geològic $i$ Geomorfològic glacial.

8. Observació dels indrets relacionats amb el patrimoni miner, que es vagi trobant al llarg del recorregut.

\section{Antecedents}

Pel que fa al recorregut del present itinerari, existeix un parell d'antecedents molt recents. Es tracta de Mata-Perelló (2013a i 2013b). També cal parlar de Martínez Rius (2013),

Pel que fa a la descripció de les mineralitzacions, cal parlar d'un altre treball, també nostre; en concret de Mata-Perelló (1991). Aquest treball es relatiu a les mineralitzacions catalanes en general, amb un capítol dedicat a la Noguera. També cal fer esment de Mata-Perelló i Sanz (1993), dedicat al reconeixement dels minerals.

I pel que fa a l'estructura geològica de la zona per la qual discorre l'itinerari, farem esment de dos treballs, molt interessants, de caràcter generalista. En concret, ens estem referint als següents: Guimerà et altri (1982). i també a Riba et altri (1976). Tots dos treballs es refereixen 
a la geologia dels Països Catalans, i conseqüentment de Catalunya. Per altra banda, també cal fer esment del treball de l'IGME (1994).

Tots aquests treballs referenciats, i d'altres, figuren esmentats per ordre alfabètic a l'apartat dedicat a la BIBLIOGRAFIA.

\section{Recorregut de l'itinerari}

El recorregut de l'itinerari discorrerà per una comarca de la Regió de Tremp - la Seu d'Urgell; concretament per la del Pallars Jussà i dintre d'aquesta per la Vall Fosca, en els seu tram superior, seguint sempre el curs del Noguera de Flamisell,

Així, el recorregut s'iniciarà a la població de la Torre de Cabdella, situada a la Vall del Flamisell, que ara remuntarem, seguint sempre la carretera local $L-503$. Aquest recorregut l'efectuarem dintre del Mantell de la Zona de les Nogueres. Posteriorment, el recorregut continuarà cap el Nord, passant per les immediacions de les poblacions d'Aiguabella i d'Espui, per on es farà una aturada.

Posteriorment, el recorregut es dirigirà cap a la localitat de Cabdella, per on es realitzaran diverses aturades, prop del contacte entre la Unitat del Mantell de les Nogueres i la Zona Axial Pirinenca.

Des taquí, el recorregut es dirigirà cap a la Presa de Sallente i cap a l'Estany Gento, per on finalitzarà el recorregut de l'itinerari. Al llarg de tot aquest recorregut, s'aniran fent diverses aturades, totes dintre de la Zona Axial Pirinenca.

\section{Advertiments previs}

Com en altres recorreguts de RECERCA GEOLÒGICA I MINERALÒGICA ..., si es disposa del temps suficient, poden efectuar-se passant per totes les parades i filloles. En cas contrari, recomanem prescindir de les anomenades PARADES - CONDICIONALS.

També cal tenir en conte que una petita part del recorregut de l'itinerari, es realitzarà per camins de terra, per la qual cosa caldrà prendre les degudes precaucions. Per d'altra banda, una part del recorregut es realitzarà a peu (la darrera), tot anant des de Sallente cap a l'Estany Gento.

Cal tenir, com sempre, una cura molt especial de respecte a la natura, al llarg de tot el recorregut de l'itinerari, i també fora d'ell. 


\section{Descripció de l'itinerari}

En aquest recorregut hem situat, com ja és habitual en tots els itineraris, una sèrie d'ESTACIONS o de PARADES, que anirem veient a continuació. En cada cas, els hi donarem una denominació que podrà correspondre a algun paratge proper. També indicarem el terme municipal i la comarca on es troba.

Per d'altra banda, en cada una de les parades, indicarem entre parèntesi el número del "Mapa Topográfico", a escala 1:50.000, on es troba situada la parada considerada. En aquesta ocasió serà algun dels següents: 181 (o d'Esterri d'Áneu) i 214 (o de Sort). Tanmateix, utilitzarem el full 54 (Val Fosca) del Mapa Topogràfic de Catalunya, a l'escala 1:25.000.

Així doncs, la relació ordenada de les parades que composen aquest recorregut, és la següent.

\subsection{Parada 1 - CONDICIONAL. MUSEU HIDROELÈCTRIC DE LA TORRE DE CABDELLA, (terme de la Torre de Cabdella, Vall Fosca, comarca del Pallars Jussà). (Full 214).}

El recorregut d'aquest itinerari, el començarem a la població de la Torre de Cabdella, situada al bell mig de la vall, de la qual n'és la seva capital administrativa. Així, l'iniciarem al Museu Hidroelèctric, situat al costat de l’Ajuntament de la població.

La Torre de Cabdella, es troba situada dintre del Sistema Pirinenc, on es troba també tota la Vall Fosca. Tot i així, aquests sectors es troben situats dintre de la Unitat del Mantell de les Nogueres, però molt a prop de la Zona Axial Pirinenca. Així, per arreu, es veuen afloraments dels materials paleozoics del Devonià. Efectivament, per aquests indrets predominen els terrenys eminentment carbonatats del Devonià. Es fàcil veure trams del Devonià Mig (amb calcàries de la Formació Manyanet i pissarres de la Formació Vilaller); i també trams més propers del Devonià Inferior (amb pissarres i calcaries de la Formació Basibé i amb pissarres i calcaries de la Formació Rueda).

Tot i així, molt sovint, aquests materials es troben recoberts per terrenys neògens, del Pleistocè i de l'Holocè, d'origen glacial i fluvial, segons els indrets. Aquests terrenys neògens, tenen un clar origen glacial, relacionant-se amb la presencia de morrenes laterals i de derrubis de pendent.

En aquest indret hi ha un interessant museu: el MUSEU HIDROELÈCTRIC DE LA TORRE DE CABDELLA. Recomanem la seva visita i per fer-ho, cal adreçar-se a: I'Ajuntament; així com ferho per telèfon ( 9736630 01), per fax (973 $66 \quad 3145)$, o per via telemàtica (ajuntament@torrecapdella.ddl.net i www.vallfosca.net/museu.php). Es tracta d'un bon indret per tal de conèixer el passat d'aquesta comarca i el seu desenvolupament a partir de la construcció de les diferents centrals hidroelèctriques. Aquestes, en conjunt, van contribuir també a la industrialització de Catalunya. 


\subsection{Parada 2 - CONDICIONAL. INICI DEL CAMÍ D’ESPUI CAP EL COLL DE TRIADOR, (Espui, terme municipal de la Torre de Cabdella, la Vall Fosca, comarca del Pallars Jussà). (Full 214).}

Després de realitzar la parada anterior, cal continuar cap el Nord, remuntant la Vall Fosca, seguint la carretera local $L-503$. En arribar a les immediacions d'Espui, podem fer una nova aturada, després de recórrer uns 4’5 Km, aproximadament. Abans d'arribar a l'indret de l'aturada, haurem deixat per la dreta el trencall d'Aiguabella.

La població d'Espui, es troba situada dintre del Sistema Pirinenc, on es troba també tota la Vall Fosca. Tot i així, aquests sectors es troben situats dintre de a Unitat del Mantell de les Nogueres, però molt a prop de la Zona Axial Pirinenca. Així, per arreu, es veuen afloraments dels materials paleozoics del Devonià. Tanmateix, prop d'aquest indret, més amunt, també trobarem afloraments de les pissarrres fosques del Silurià.

Per d'altra banda, des d'aquest indret, prop del pont sobre el Noguera de Flamisell, es pot veure la morfologia glacial d'aquesta vall.

\subsection{Parada 3. IMMEDIACIONS DE L'ESGLÈSIA DE CABDELLA, (Cabdella, terme municipal de la Torre de Cabdella, comarca del Pallars Jussà). (Full 214).}

Des de la parada anterior, cal seguir cap el Nord, a través de la carretera local $L-503$, remuntant la Vall Fosca, per on circula el Noguera de Flamisell. En aquest recorregut es passarà per les immediacions de la Central de Cabdella (situada a la dreta de la carretera). Finalment, s'arribarà al proper poble de Cabdella. En arribar al darrer poble esmentat, ens caldrà anar cap al costat de l'Església, per on farem una nova aturada, a $3 \mathrm{Km}$ d'Espui. En aquest indret hi ha un mirador, des del qual podem fer diverses observacions, per arreu de la vall.

En aquest recorregut, hem continuat trobant afloraments dels materials paleozoics (primer del Devonià, i després del Silurià i de I'Ordovicià). Hem passat de la Unitat del Mantell de les Nogueres a la Zona Axial Pirinenca on estem ara situats. En efecte, poc abans d'entrar a Cabdella, hem creuat un conjunt de fractures (d'arrumbament $E-W$ ), que posen en contacte les dues subunitats pirinenques. Així, ara, per arreu es veuen afloraments dels materials paleozoics de I'Ordovicià i del Cambro - Ordovicià (amb trams d'esquistos i quarsites, fonamentalment). Tot i això, aquests materials es troben recoberts, molt sovint per terrenys detrítics cenozoics, neògens (del Pleistocè i de l'Holocè), d'origen generalment glacial o fluvial, segons els indrets.

Des d'aquest indret., mirat cap el Sud, es pot gaudir d'una bona observació de la Vall Fosca, per on hem estat circulant. I també on estem encara ubicats en aquesta parada. (fotografies 1 , $2,3$ i 4$)$. 


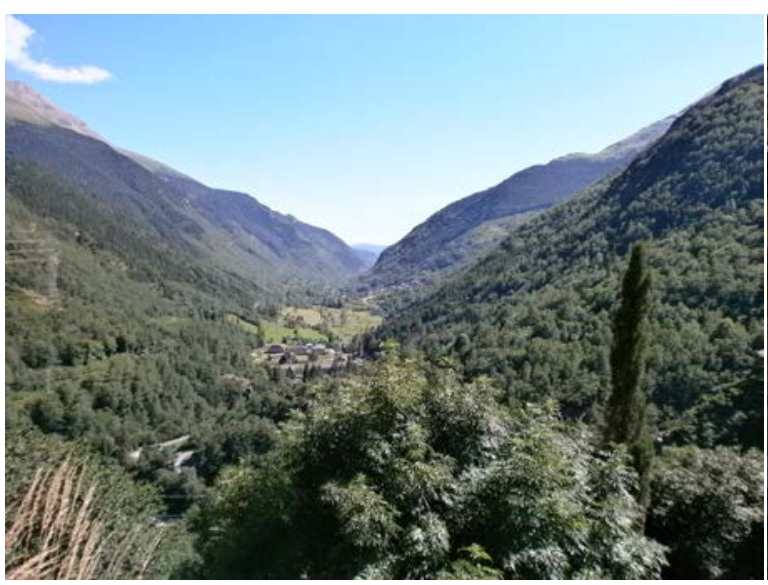

Fotografia 1. La Vall Fosca des de l'Església de Cabdella. Es pot veure la morfologia fluvio - glacial / Juliol 2013

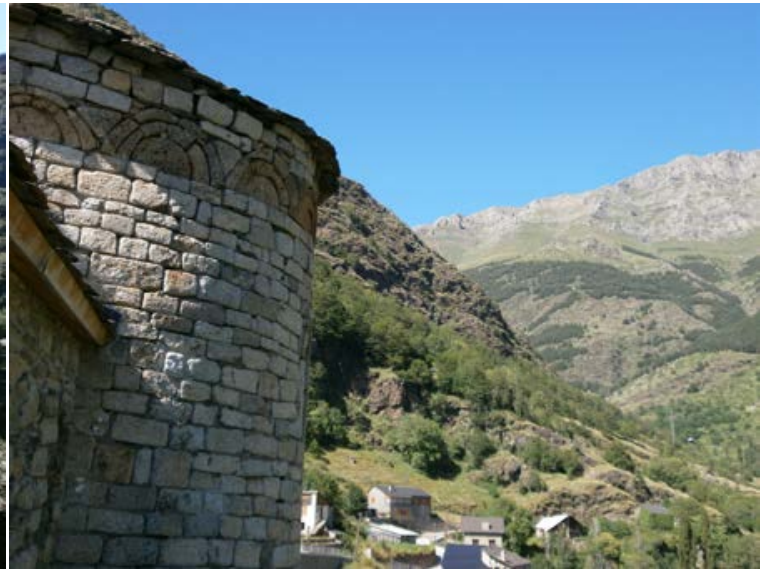

Fotografia 2. La Vall Fosca des de l'Església de Cabdella, mirant cap el Nord. Es pot veure la morfologia fluvio - glacial, de la vall de Sallente / Juliol 2013

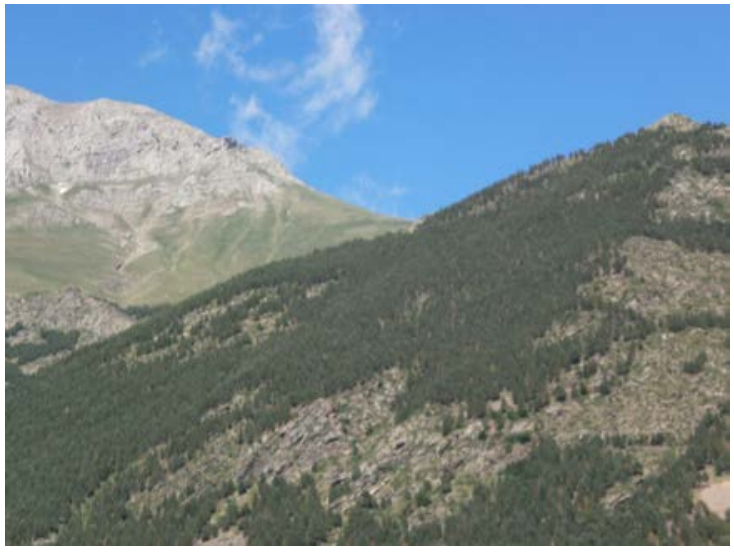

Fotografia 3. Sectors meridionals del Montsent de Pallars, des de l'Església de Cabdella. Es veuen els afloraments dels materials del Devonià, d'aquest relleu pallarès. Juliol 2013

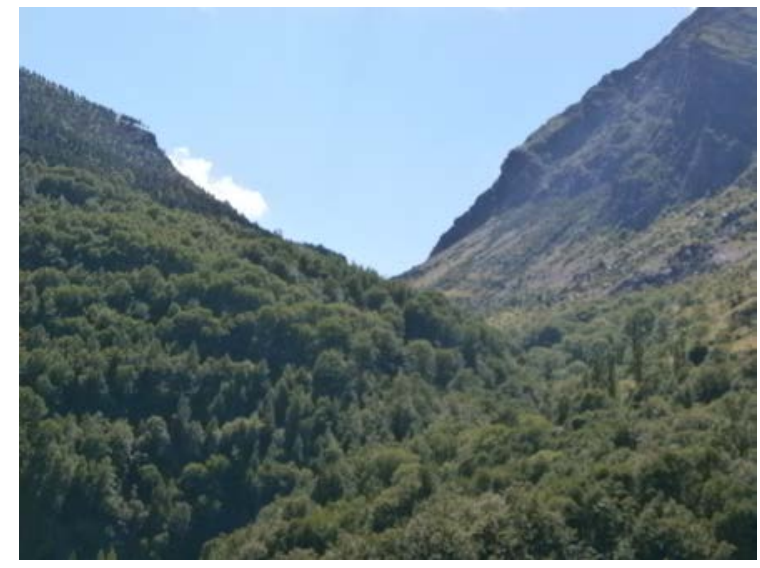

Fotografia 4. La Vall de Filià (situada sobre Espui), des de l'església de Cabdella. Es pot veure la morfologia glacial d'una vall afluent penjada. Juliol 2013 


\subsection{Parada 4. IMMEDIACIONS DEL BARRANC DE RICOSSANTO, (Cabdella, terme municipal de la Torre de Cabdella, comarca del Pallars Jussà). (Full 214).}

Des de la parada anterior, cal retornar a la carretera principal de la Vall del Flamisell, per tal de continuar cap amunt, remuntant sempre la vall de la Noguera del Flamis ell. Després de sortir de Cabdella, trobarem una sèrie de revolts, per on es puja cap a la part alta de la vall. En un d'aquests revolts, podem fer una nova aturada, a menys de $1 \mathrm{Km}$ de l'anterior.

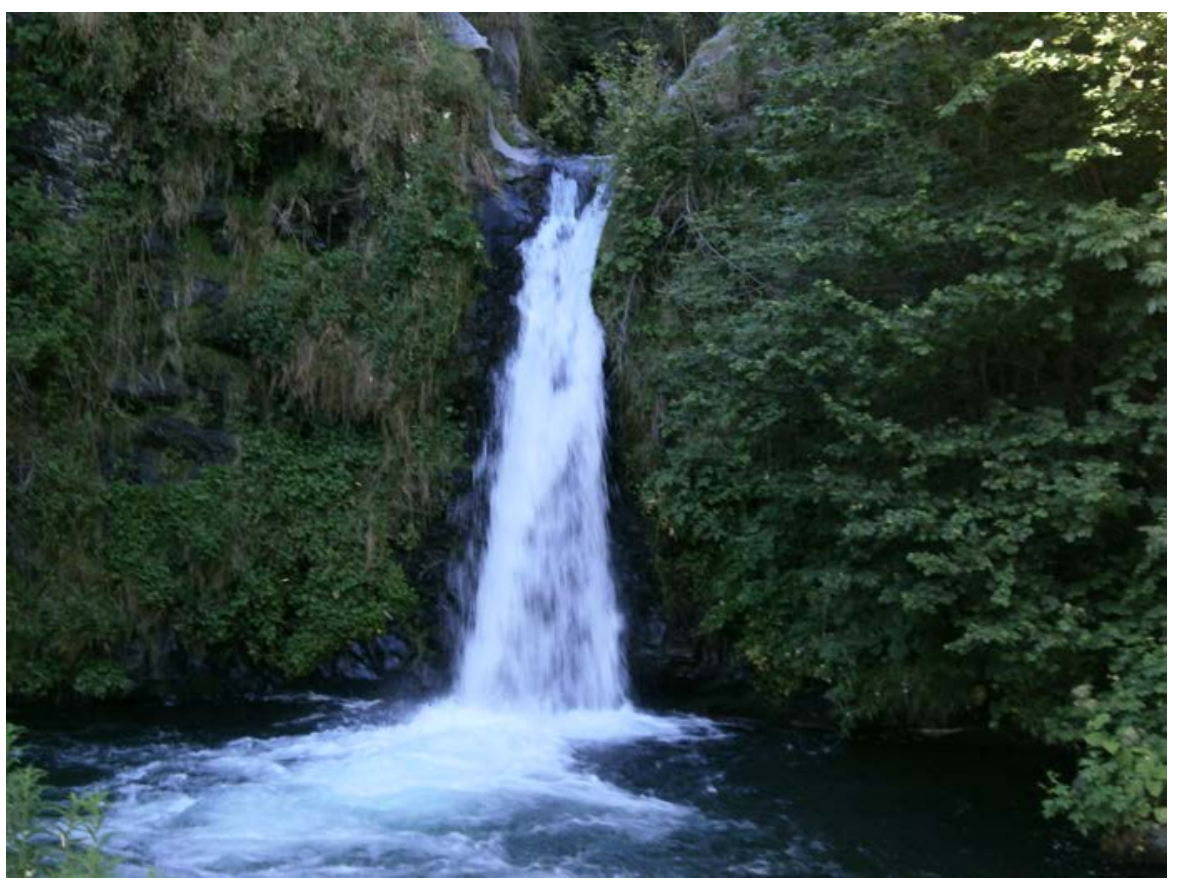

Fotografia 5. Cascada de Cabdella / Juliol 2013

En aquest indret, hi ha un aflorament de roques detrítiques, d'origen morrènic. Així, es veuen fragments hetrogènics de calcàries, granits, pissarres, corneanes i esquistos, fonamentalment. Els blocs tenen mides molt variades, predominant els blocs grans de granit, sovint redondejats. Es presenten dintre d'una matriu argilosa - sorrenca.

Abans d'arribar a aquest indret, haurem creuat el riu que baixa de Sallente i del Pla de la Toveria (on anirem després). Aquest és el Noguera de Flamisell, que en arribar a aquest indret, forma una interessant cascada (fotografia 5), originada per la diferencia de nivell de la Vall del Flamisell i de la Vall de la Ribera de Rigüerna, que baixa des de Rus i fan l'aiguabarreig prop de Cabdella. 


\subsection{Parada 5. CARRETERA DE CABDELLA CAP A SALLENTE, PLA DE TOVERÍA, (Cabdella, terme municipal de la Torre de Cabdella, comarca del Pallars Jussà). (Full 214).}

Després de fer l'aturada anterior, ens cal continuar per la carretera que procedeix de Cabdella i que es va dirigint cap a Sallente. Després d'un conjunt de corbes, arribarem al Pla de Toveria, per on farem una nova aturada. Així, des de l'anterior, haurem recorregut uns 1'5 - 2 Km més i escaig.

En aquest recorregut, s'haurà fet més palès, que estem plenament situats dintre de la Zona Axial Pirinenca (dintre dels anomenats Apilaments Antiformes de la Zona Axial Pirinenca). Així, per arreu, s'han fet palesos els afloraments dels materials paleozoics de l'Ordovicià $i$ del Cambro - Ordovicià, amb esquistos, corneanes i quarsites, fonamentalment.

Tanmateix s'han fet cada cop més palesos els recobriments dels materials detrítics cenozoics, del Neogen, concretament del Pleistocè i de l'Holocè. Així, per arreu es fan palesos els afloraments de les morrenes glacials, amb freqüents blocs de granits $\mathrm{i}$ de granodiorites, procedents de la part més alta de la vall.

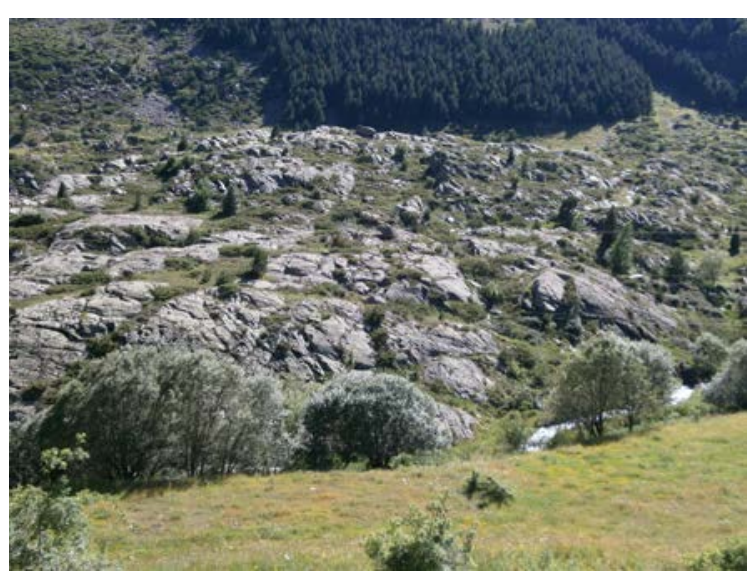

Fotografia 6. Superfície d'arrossegament dels glacials i estries, sobre els esquistos de l'Ordovicià.

Juliol 2013

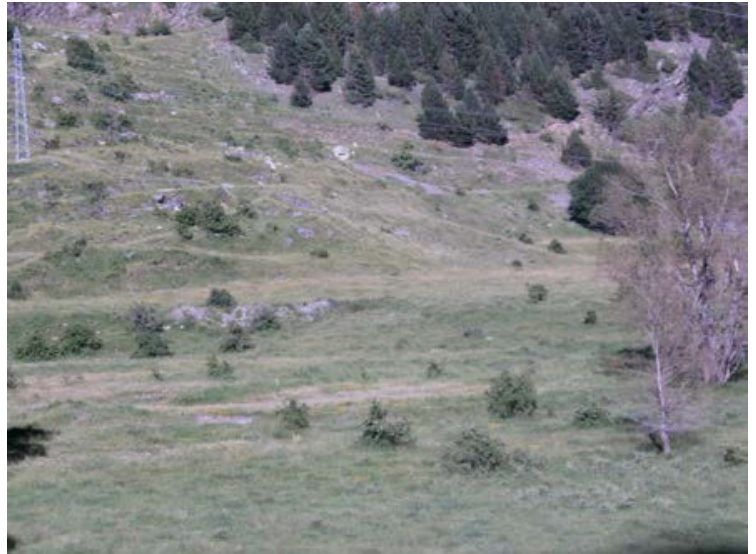

Fotografia 7. Un aspecte del Pla de Toveria. Correspon a un antic llac glacial, de sobre excavació del glacial. Ara es troba reblert per sediments fluvial del Flamisell. Juliol 2013

Igualment, s'ha anat fent cada vegada més palesa la morfologia glacial de tot aquest conjunt. En efecte, per arreu es veuen blocs erràtics, estriacions d'arrossegament entre les roques de la vall. Fins i tot es veu l'indret on hi va haver un antic llac glacial (ara reblert), que correspon al Pla de Toveria. Això, es pot veure a les (fotografies 6 i 7 ). 


\subsection{Parada 6 - CONDICIONAL. PEDRERA DE L'EMBASSAMENT DE SALLENTE, (Cabdella, terme municipal de la Torre de Cabdella, comarca del Pallars Jussà). (Full 181).}

Després de realitzar la parada anterior, cal continuar per una carretereta que condueix cap a I'Embassament de Sallente. Després d'un recorregut d'uns 2'5 Km, aproximadament, hi arribarem. En aquest indret, una nova aturada del recorregut d'aquest itinerari. La farem front a una antiga pedrera, situada a l'esquerra de la carretera.

Aquest recorregut, l'hem efectuat entre afloraments dels materials paleozoics, que en bona part pertanyen a I'Ordovicià. I també al Cambro - Ordovicià. Així, al llarg d'aquest recorregut, haurem trobat esquistos, fil.lites i quarsites, fonamentalment. Per d'altra banda, ens hem estat desplaçant sempre per la Zona Axial Pirinenca (Apilaments Antiformes de la Zona Axial Pirinenca) on estem ara situats.

En aquest indret, va haver-hi una antiga explotació de les roques del Cambro - Ordovicià, les quals es van emprar per a la construcció de la presa de I'Embassament de Sallente. Cal dir que es tracta d'una explotació en bancs que no ha estat mai restaurada. Aquest fet provoca un clar impacte sobre la zona. (fotografia 8).

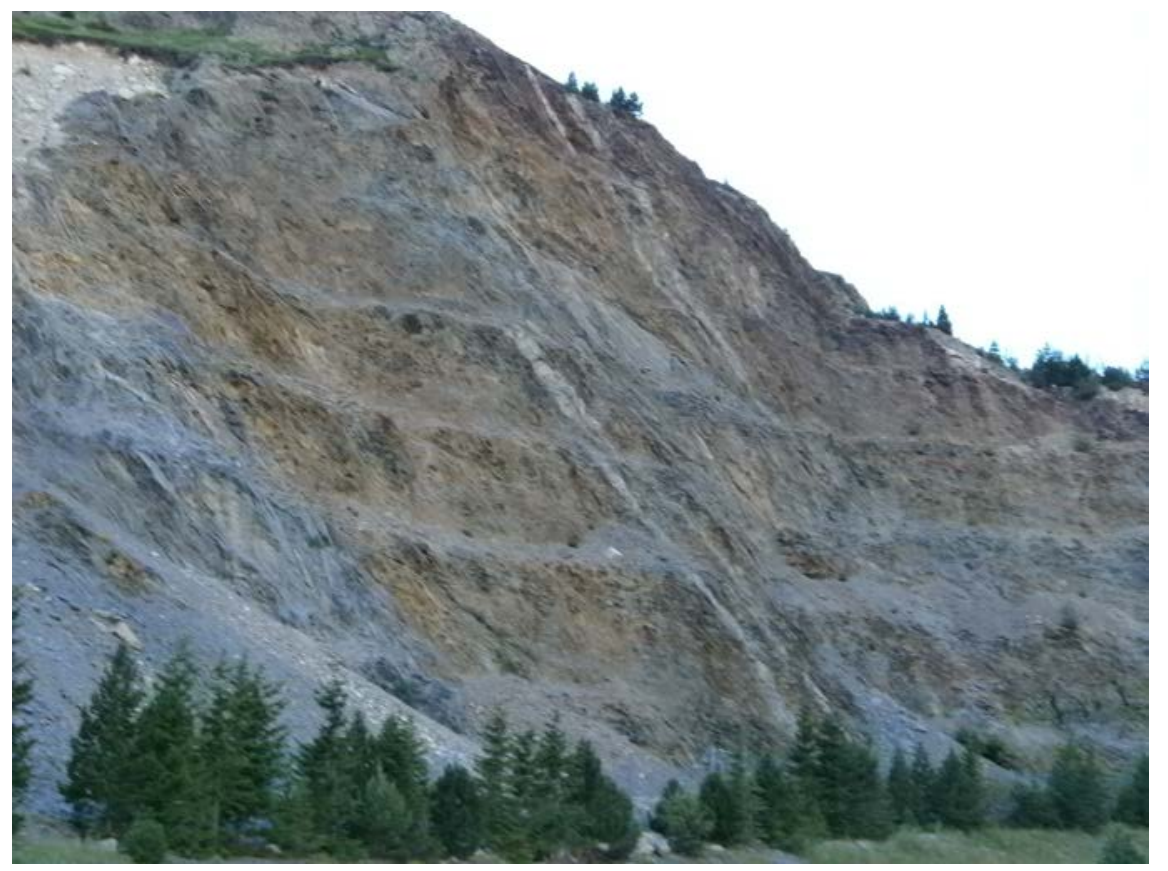

Fotografia 8. Un aspecte de l'explotació dels materials del Cambro - Ordovicià, per tal d'ésser emprats per a la construcció de la Presa de l'Embassament de Sallente. Es pot observar la manca de restauració. Agost del 2013.

Pel fa a la presa, cal dir que s'han utilitzat els materials estrets a aquesta pedrera. Finalment, cal dir que és un bon exemple de Presa d’Escullera. 


\subsection{Parada 7. EMBASSAMENT DE SALLENTE I SISTEMA SALLENTE - ESTANY GENTO, (Cabdella, terme municipal de la Torre de Cabdella, comarca del Pallars Jussà). (Full 181).}

Després de realitzar la parada anterior, cal continuar per la carretereta que condueix cap als sectors septentrionals de l'Embassament de Sallente. Després d'un recorregut d'uns $1 \mathrm{Km}$, aproximadament, hi arribarem. En aquest indret, una nova aturada del recorregut.

Aquest recorregut, l'hem efectuat entre afloraments dels materials paleozoics, que en bona part pertanyen a I'Ordovicià. I també al Cambro - Ordovicià. Així, al llarg d'aquest recorregut, haurem trobat esquistos, fil.lites i quarsites, fonamentalment. Per d'altra banda, ens hem estat desplaçant sempre per la Zona Axial Pirinenca (Apilaments Antiformes de la Zona Axial Pirinenca) on estem ara situats.

Per d'altra banda, en arribar a la part més septentrional de l'Embassament de Sallente, haurem vist com es fan clarament palesos els afloraments de les roques granítiques. Aquestes encavalquen a les roques metamòrfiques que fins ara hem anat trobant, especialment en el recorregut fet des de la població de Cabdella. (fotografia 9).

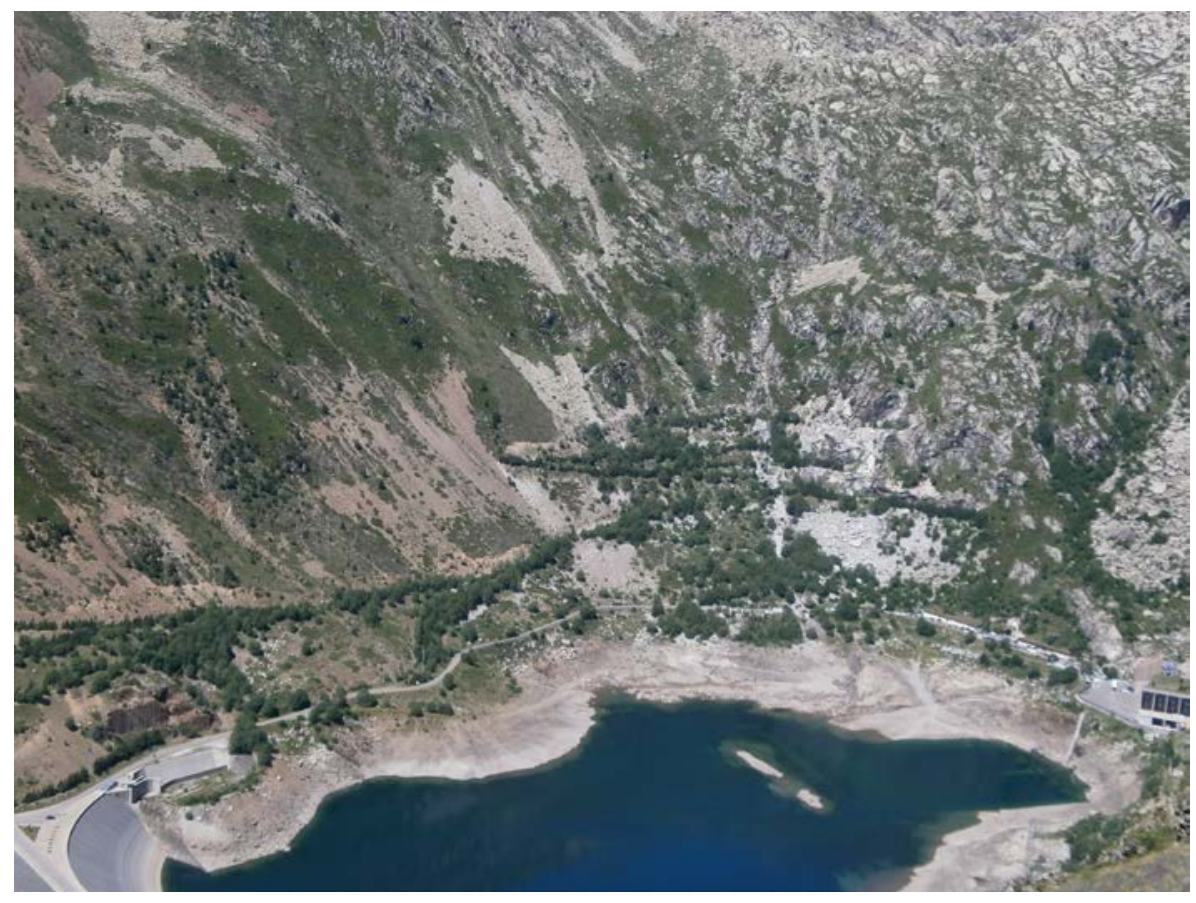

Fotografia 9. Un aspecte del contacte entre les roques metamòrfiques del Cambro - Ordovicià i les roques granítiques (i granodiorítiques) del Carbonífer. Les segones encavalquen a les primeres Visible, des del camí de Sallente a l'Estany Gento. Agost del 2013.

Tot i així, per tot arreu es fan palesos els recobriments dels materials anteriors, per part de depòsits neògens detrítics, generalment de procedència glacial, del Pleistocè i de l'Holocè, que es relacionen amb depòsits morrènics.

Per altra banda, en aquest lloc hi ha un interessant embassament, construït sobre la vall del riu Sallente. Aquest embassament forma part del sistema hidràulic Estany Gento - Sallente. En efecte, aquí es recullen les aigües de diversos llacs d'origen glacial, destinats a l'obtenció d'energia hidroelèctrica. Al mateix temps, aquest és un llac reversible, de forma que 
periòdicament les aigües es bombegen cap a l'Estany Gento, situat més amunt, ja dintre del Parc Nacional d'Aigües Tortes - Sant Maurici. Aquest sistema, és un dels més importants de tot els Pirineus i de la Península Ibèrica.

Per altra banda, a la bora del mateix embassament, es fa també palesa l'aureola metamòrfica, veient fil-lites i cornianes, de tonalitats rogenques. (fotografia 10 ).

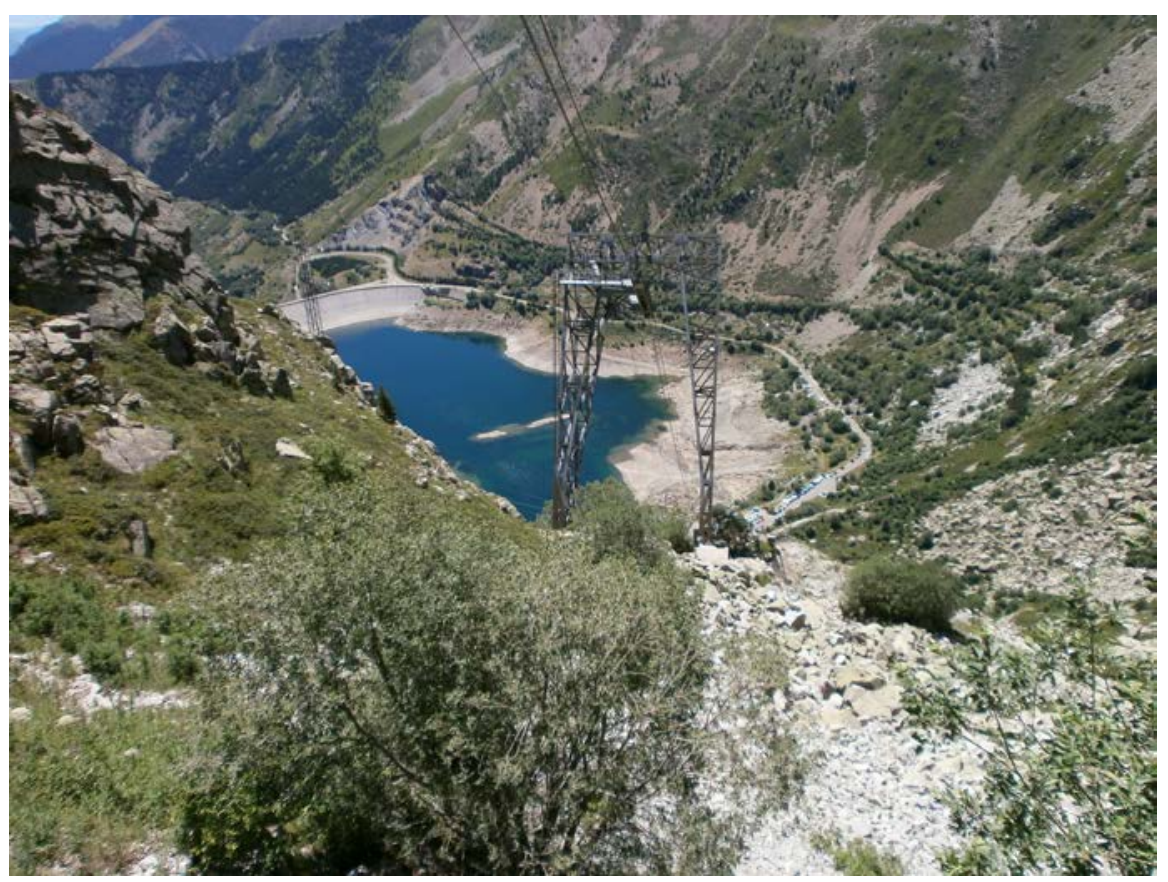

Fotografia 10. L'embassament de Sallente, vist des del Refugi de I'Estany Gento. Al fons es veuren les roques grises metamòrfiques de l'Ordovicià i Cambro - Ordovicià. Pel centre es fa palesa l'Aureola Metamòrfica. En primer terme es veuen les roques granítiques. Agost 2013

Des d'aquest indret es pot veure com l'aigua procedent de l'Estany Gento (el Torrent de l'Estany Gento) va baixant en cascada fins a l'indret on ara som, a la denominada cubeta de Sallente. Això es conseqüència de la diferencia d'alçades de les dues cubetes, la de l'Estany Gento i la de Sallente.

Per d'altra banda, voltant pels entorns de Sallente, es poden veure nombrosos exemples de morfologia glacial, com arrossegaments, amb estries ben marcades. També es pot veure a la fotografia 11, que correspon a un aflorament de les granodiorites situades per sobre de la galeria de comunicació. 


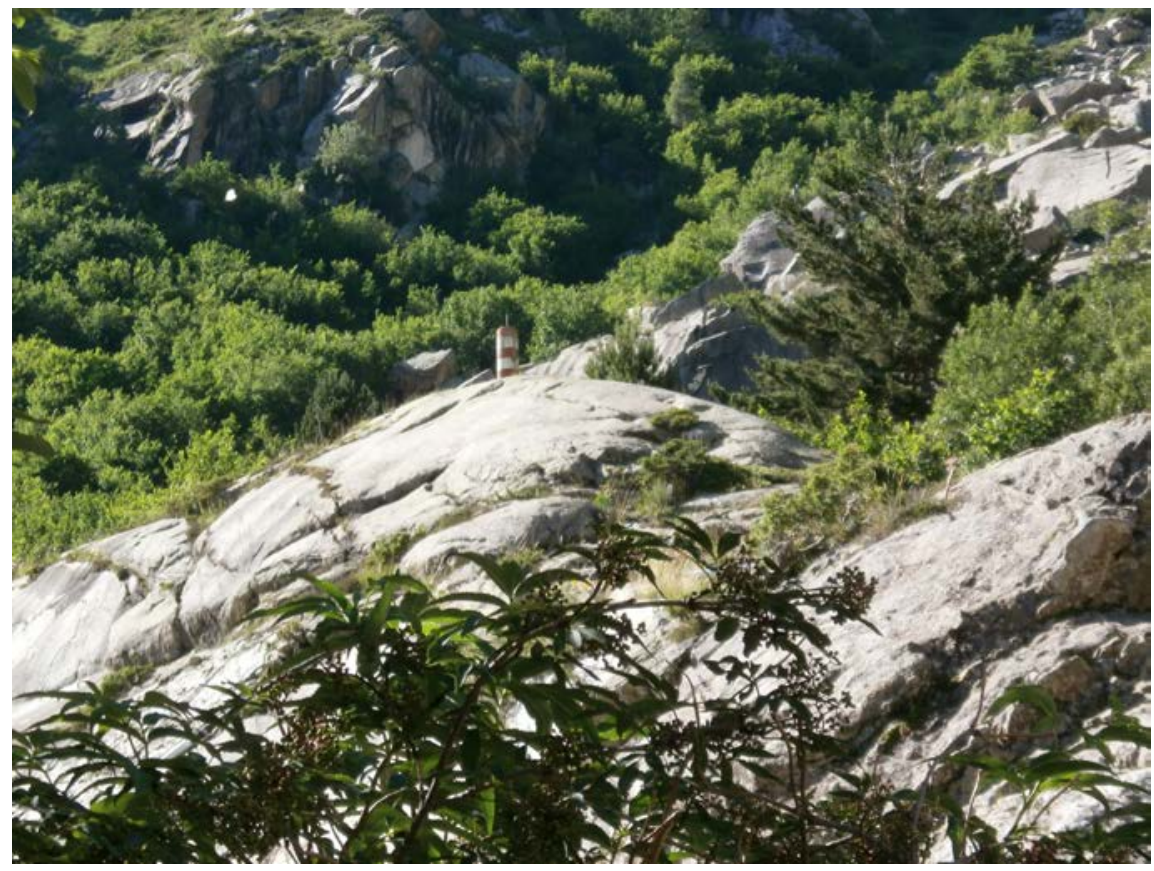

Fotografia 11. Blocs de granits, dels sectors septentrionals de Sallente, amb evidents mostres d'arrossegament glacial, amb estries. Juliol 2013.

\subsection{Parada 8. ESTANY GENTO, (Cabdella, terme municipal de la Torre de Cabdella, comarca del Pallars Jussà). (Full 181).}

Des de la parada anterior, cal retornar cap a la presa de Sallente, per tal d'iniciar un recorregut a peu, el qual ens portarà cap a l'Estany Gento. Així, hi arribarem en un recorregut a peu de $1 \mathrm{~h}$ 30 min - 2hores, havent pujat un desnivell de poc més d'uns 370 metres.

Com és evident, aquest recorregut, l'haurem fet. Íntegrament, per la Zona Axial Pirinenca, on ens trobem des de la segona aturada del recorregut d'aquest itinerari. Així, haurem vist afloraments dels materials de l'Ordovicià (amb esquistos, fill lites i quarsites), que són els que apareixen pels voltants de la pressa de l'embassament.

Més amunt, haurem començat a trobar afloraments dels materials granítics (fonamentalment: granits i granodiorites). Aquests materials són els que apareixen pels voltants de l'Estany Gento, on estem ara situats. Així, per arreu es poden veure afloraments d'aquestes roques d'edat carbonífera, relaciones amb el plegament variscic (o hercinià).

l'Estany Gento, constitueix un dels principals llacs dels Pirineus de Catalunya. Te una clara morfologia glacial, formada pel soscavament de les glaceres sobre les roques granítiques acabades d'esmentar. Alhora, forma part de l'important complex lacustre de la Vall Fosca, format per nombrosos llacs, com els propers Estany Mar i Estany Tort, entre molts altres que donen les aigües al Noguera de Flamisell. (fotografia 12). Precisament, totes les aigües dels llacs anteriors i les d'altres, de tot el complex lacustre de la Vall Fosca, són canalitzades cap l'embassament de Sallente, que hem vist a la parada anterior. Cal dir, que des de el camí d'ascens cap a l'Estany Gento i des del mateix llac, es poden gaudir d'unes interessants vistes de l'Embassament de Sallente. 


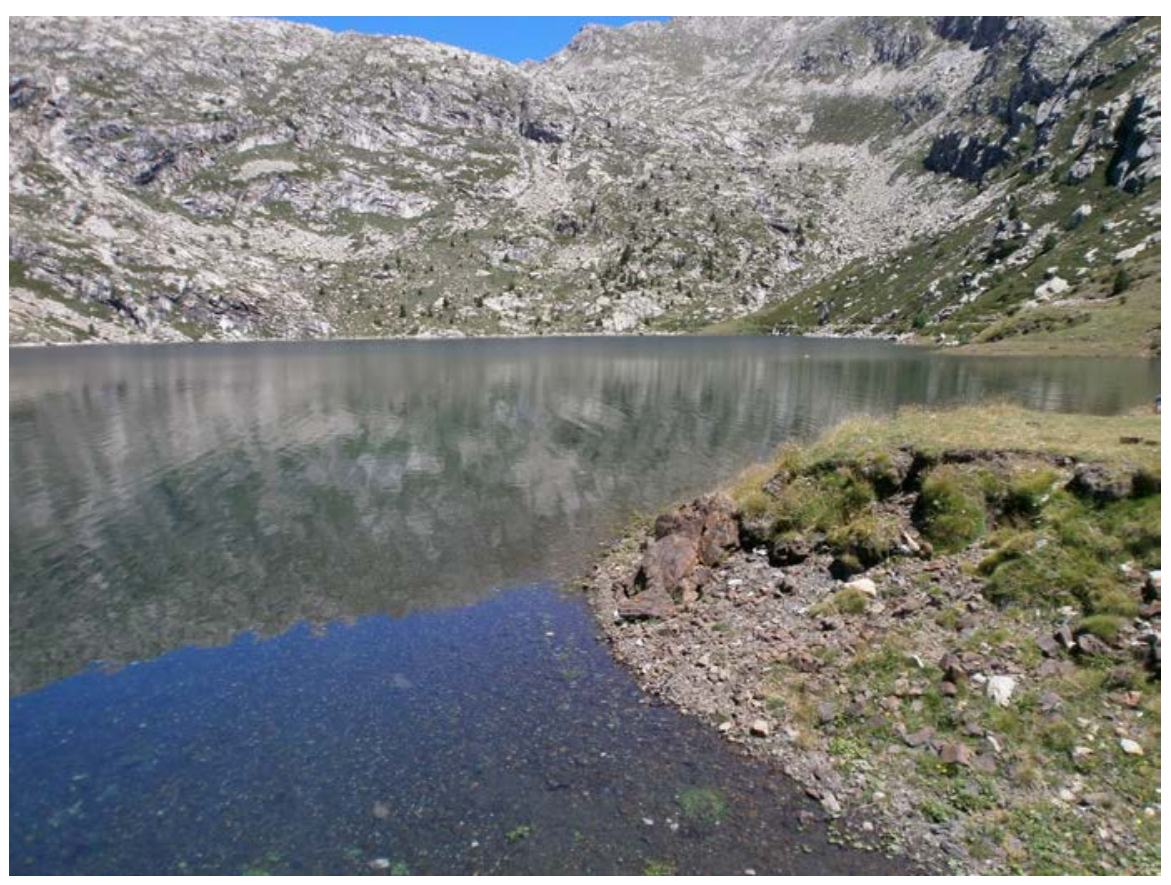

Fotografia 12. L’Estany Gento, entre afloraments de roques granítiques. Agost 2013

En aquest indret finalitza el recorregut de l'itinerari. 


\section{Bibliografia}

GUIMERÀ, J. et altri (1992).- Geologia (II), Història Natural dels Països Catalans, Vol. 2, 547 pag. Enciclopèdia Catalana, S.A. Barcelona

IGME (1994).- Mapa Geológico de España a escala 1:50.000 (Plan Magna). Fulla i Memòria no 252 (Tremp). Inst. GeoMinero y Tecnol. España. Minist. Indústria. Madrid

MARTínEZ RIUS, A. Et altri (2013).- Guia Geològica del Parc Natural d’Aigüestortes i Estany de Sant Maurici. Publicada a Guies Geològiques dels Parcs Nacionals (dirigida per Roberto Rodríguez Fernández). IGME -Edit Everest. 225 pàgines. Madrid

MATA-PERELLÓ, J.M. (1991).- Els Minerals de Catalunya. Arxius de la Secció de Ciències de I'Institut d'Estudis Catalans, vol.47, 545 pàgines. Barcelona.

MATA-PERELLÓ, J.M. (2013a).- Recorregut de recerca geològica i mineralògica per la comarca del Pallars Jussà: des de Senterada, a la Pobleta de Bellveí, a la Plana de Mont-ros, a Cabdella i a Sallente. Inèdit. 14 pàgines. Manresa

MATA-PERELLÓ, J.M. (2013b).- Recorregut de recerca geològica i mineralògica per la comarca del Pallars Jussà: des de la Torre de Cabdella cap a Cabdella, Sallente i cap I'Estany Gento. Inèdit. 12 pàgines. Manresa

MATA-PERELLÓ, J.M. i SANZ BALAGUÉ, J. (1993).- Guía de identificación de Minerales, adaptada fundamentalmente a la Península lbérica. Parcir, Edic. Selectas, 243 pàgines. Manresa

RIBA ARDERIU, O. et altri (1976).- Geografia Física dels Països Catalans. Edit Ketres. 211 pàgines. Barcelona. 